Article

\title{
Claims of Misrepresentation: A Comparison of Germany and Brazil
}

\author{
Petra Guasti ${ }^{1, *}$ and Debora Rezende de Almeida ${ }^{2}$ \\ ${ }^{1}$ Research Unit Democratic Innovations, Goethe University Frankfurt, 60323 Frankfurt am Main, Germany; \\ E-Mail: guasti@soz.uni-frankfurt.de \\ 2 Political Science Institute, University of Brasília, 70910-900 Brasília, Brazil; E-Mail: deboraalmeida@unb.br \\ * Corresponding author
}

Submitted: 30 March 2019 | Accepted: 8 July 2019 | Published: 24 September 2019

\begin{abstract}
The system of representative democracy is under considerable strain. Its institutions are struggling to maintain legitimacy, and its elected representatives are failing to keep their monopoly on (formal) political representation. An emerging multitude of (new) claim makers contests the authority of elected representatives as well as the functioning of the existing system of representative democracy by alleging misrepresentation. In this article, we identify a significant shortcoming in Saward's claims-making approach; specifically, we argue that it offers little direction in addressing misrepresentation. We distinguish between claims of representation and claims of misrepresentation, and show how the latter can fulfill one, two or all three of the following functions: (1) they appeal to an enemy/antagonist (strategy), (2) identify causes of misrepresentation related to policies, politics, and polity (persuasion), and (3) claim to create a new linkage to "the people", sometimes present themselves as new representatives (reframing). To test this proposed framework, we compare claims of misrepresentation in Brazil made by civil society groups (before and during the presidential impeachment between 2014 and 2016) and in Germany (focusing on the parliamentarians of the Alternative for Germany during the first six months of mandate). Our results suggest that claims of misrepresentation are not intrinsically democratic or undemocratic, but are instead ambiguous, have different manifestations and disparate impacts on the representative system. Our article contributes to the conceptual development of the claims approach and to further understanding several critical and current challenges to representative democracy.
\end{abstract}

\section{Keywords}

Brazil; democracy; Germany; misrepresentation; populism; representation; representative claims

\section{Issue}

This article is part of the issue "Rethinking Representation: Representative Claims in Global Perspective", edited by Petra Guasti (Goethe University Frankfurt, Germany) and Brigitte Geissel (Goethe University Frankfurt, Germany).

(C) 2019 by the authors; licensee Cogitatio (Lisbon, Portugal). This article is licensed under a Creative Commons Attribution 4.0 International License (CC BY).

\section{Introduction}

Since the late 1990s, the concept of political representation has made a comeback, and has returned to the fore of democratic theory. Two contemporary political problems have driven the revival of representation, which go to the core of the standard account of representative democracy based on the centrality of elections as authorization and accountability mechanisms. First, the growing sense of crisis of representative democracy related to the decrease of trust in political elites and in- stitutions along with the disengagement with electoral democracy. Second, contemporary politics is no longer confined to the halls of parliaments. Representative institutions around the world are being contested by an emerging multitude of (new) actors claiming to represent non-territorial issues (e.g., globalization, climate change, and identities). Interest groups contribute to redefining both the constituencies and the representatives (cf. Saward, 2008).

These political developments have inspired theorists to question the polarity between representation 
and democracy, and the exclusivity of elections as the main source of legitimacy (Mansbridge, 2003; Plotke, 1997; Rehfeld, 2006). Representation is no longer an alternative to direct democracy, but enables the continuous participation-even if indirectly-and the inclusion of citizens during the political processes (Urbinati, 2006). Furthermore, the notion that interests and identities are endogenous to representative politics and constructed by electoral and non-electoral, formal and informal representatives, is key to the "representative turn" in democratic theory. The representative turn embraces different vocabularies and analytical-theoretical proposals (Saward, 2010; Vieira, 2017).

This article contributes to the development of the representative claims approach by focusing on the performative and constructivist aspects of representation. We follow Saward and define representation as a practice performed by claims, which may be expressed through a variety of sites, processes, and actors (Saward, 2006, 2010). In this performance, makers present themselves or others as speaking, embodying, symbolizing an idea or image (referent) of the constituency (object) and offered claims to an audience. Saward's approach allows us to analyze competing and different claim-makers: Marine Le Pen speaking 'in the name of the people' and Emmanuel Macron seeking to be 'the president of all the people of France' in the 2017 French Presidential elections. It also allows us to study claims by non-elected claim makers-such as students demanding action on climate change in March 2019 ("If you do not act like adults, we will"), or US students demanding gun control in March 2018 ("We are the change").

However, Saward's (2010) focus on positive claims offers little direction in addressing negative claims or claims of misrepresentation, which have become even more relevant in contemporary politics. The only two references to misrepresentation treat it as a consequence of malfunctioning of the representative system; or as unavoidable due to the incompleteness of political representation. We argue instead that claims of misrepresentation are constitutive of the claims-making process. They express not only the constituencies' dissatisfaction, but also can serve as part of a strategy and political style intended to discredit opponents and thereby to persuade the audience. As such, claims of misrepresentation have the potential to specifically affect the political system, and in particular to deepen the democratic deficit and cultivate political crisis (Moffitt, 2016; Urbinati, 2019).

To unpack claims of misrepresentation, we build on contributions from the literature on political crisis and populism, and use them to further develop the performative understanding of representative claims (Saward, 2017). Unpolitical discourses represent forms of counter-democracy to monitor and control representatives (Rosanvallon, 2008). Counter-democracy can engender negative effects and deepen the representative gap by simultaneously undermining the discourses of elected representatives and stressing the role of alternative claim makers, using the audience as an alternative form of 'legitimacy' (Urbinati, 2006, 2010). In the context of such growing spectacularization of politics, representatives tend to adopt discourses oriented toward specific audiences in order to gain support (Moffitt, 2016). Claims of course must tap into familiar frameworks to be compelling (Saward, 2010). Democratic crisis and misrepresentation have a strong appeal in the contemporary social and cultural context, and serve as an example of a familiar framework. The literature on populism highlights anti-political, anti-party, and anti-establishment discourses and strategies, which enable us to discuss the challenges that claims of misrepresentation present to representative democracy (Hartleb, 2015; Kaltwasser, 2014; Schedler, 1996).

We seek to disentangle the claims of misrepresentation, and to identify the claimants. Specifically, we unpack how claims of misrepresentation are strategically constructed to void the existing linkage between representatives and the constituency, to delegitimize political opponents and to create a new, direct linkage by dividing the world into friends and enemies (cf. Buštíková \& Guasti, 2019). We focus on the variety of causes identified by claimants in order to appeal to the audience, and how they construct new linkages to solve the problem, sometimes presenting themselves as new representatives. Student climate activists illustrate this phenomenon: they claim that lack of action on climate change by elected representatives is endangering their future: "We are missing our (school) lessons, so that we can teach you one." Second, students claim that solutions to climate change are known, and there is no reason for politicians not to act other than the lack of political will, self-interest or moral corruption of the politicians (and 'adults' as a whole). Third, the students perform representation, casting themselves as the new representatives: "Hey adults, we will take it from here", forming a new constituency-future voters.

We adopt a comparative approach to assessing this framework. Focusing both on the Global North and the Global South provides significant variation in representative claims made by different actors in different arenas (cf. De Wilde, 2019), and also allows us to identify patterns and themes across different political contexts. Among the potential claimants that have exploited claims of misrepresentation, we choose civil society representatives that participate intensely in public debate and mobilization during the Brazilian presidential impeachment (2014-2016), and representatives of the Alternative for Germany (AfD) during the first six months of their mandates in the German Parliament (2017-2018). These debates focus on different substantial issues, take place among different actors (elected/non-elected), within different sites (electoral and non-electoral arena; online and face-to-face debate), appeal to different constituencies and propose different solutions. 
Notwithstanding the many differences between the cases under study, both have experienced similar moments of political rupture to the existing system, and an increasing rejection of the political establishment and status quo. The majority of claims of misrepresentation present new political demands, while challenging the legitimacy and authority of the elected representatives regarding what they do (policies), how they do it (politics) and for whom they do it (polity). However, differences remain in the emphasis that the actors give to the types of causes of misrepresentation in each country. In this article, we do not seek to explain the causes of the 'misrepresentation' but rather to reflect on contemporary challenges to representative democracy by producing a novel framework for the analysis of (claims of) misrepresentation.

The remainder of the article proceed as follows. The first section presents the theoretical framework, starting from the representative and constructivist turn in democratic theory. After presenting the claims-making approach, we highlight some limitations in Saward's account and propose a new direction to analyze the claims of misrepresentation. The second section explains the methodological orientation and techniques. The third and fourth sections present the Brazilian and German claims of misrepresentation, based on different sources of data and political contexts. Finally, we draw some conclusions regarding the similarities and differences between the cases, and discuss the effects of negative claims on democratic representation.

\section{What Type of Claims? Performance and the Challenges of Democratic Representation}

The growing tensions between representation and democracy in the rapidly changing political context have led to a significant revival in the study of representationthe 'representative turn' in democratic theory-that questions the level of importance that elections play in representation, and proposes the inclusion of others forms of non-electoral representation (Mansbridge, 2003; Näsström, 2015; Plotke, 1997; Rehfeld, 2006; Vieira, 2017). Representation is constructive. It generates knowledge, enables the capacity to share insight and to resolve conflicts (Plotke, 1997, p. 31). As such, democratic politics is partially constituted through representation. The main aim of the constructivist approach to representation is to open up (theoretically) new ways of thinking about the relationship between representation and democracy. For example, it expands participation in representative forms, and enhances communication by the combination of political judgement and will of the people (Plotke, 1997; Urbinati, 2006). In addition to the reform of representative government, more and more special-interest groups, civil society organizations, and social movements are responsible for diversifying political representation and questioning the boundaries between formal and informal representations. To empiri- cally examine democratic mechanisms, we need to think about the concept of representation as constructed by actors in a political arena (Mansbridge, 2003; Saward, 2006; Schmitter, 2009).

In this scenario, Saward's concept of representative claim has been proven extremely valuable, inviting us to focus on dynamics of representation rather than on forms of representation, and on what representation does rather than what it is (Saward, 2010, p. 4). In this approach, interests are not merely present, but they are themselves 'made' through representative politics, and this 'requires' concentration on the performative dimension and inbuilt flexibility of the concept of representation. As an event or series of events, representation is performed through claims (Saward, 2010, p. 36). This allows us to pay attention to a wide array of potential claimmakers, such as the actors in the electoral and party field; self-authorized representatives in individual and collective level, such as civil society organizations, NGOs, social movements and interest groups, delegated representatives and experts.

More than claiming, representatives need to show what they are doing in the sense that framing, staging, and acting are necessary to construct and negotiate collectivity (Vieira, 2017, p. 13). Performance is therefore integral to representing, and visualized from three key features:

(1) Emphasis on the constitutive character of political representation-refers to German darstellenevery act of representation includes the element of picturing. The representative (subject) becomes a representative by portraying himself/herself as such, or by being portrayed by the maker-which may be the same person-to the constituency (object) (Saward, 2010, pp. 47-48). A successful claim might or might not make a persuasive argument, but it must have a particular resonanceoften by using existing and recognizable frameworks (frames);

(2) What is represented (the object of the claim) is the idea of the represented (Saward, 2010, p. 36); claim-makers construct verbal and visual images of their constituencies-and claim to put different 'ideas' of the represented into play (referent), which are always partial and opened up for contestation;

(3) Representation is neither bad nor good, in principle, but needs to be "read back" by the constituency/object and audience, responsible for judging the (legitimacy of) representative claim. This is the theatrical element of the performative aspect-representation through claims only works if claims are acknowledged by the audience (acceptance, rejection, engagement).

There is growing criticisms of this approach. It focuses on the destabilization of the traditional distinction between 
participatory and representative politics, the distinction among the elements of constructivist processes, and the normative insufficiencies of constructivism to assess political representation as democratic (Almeida, 2018; De Wilde, 2013; Disch, 2015; Näsström, 2015, p. 507).

In this article, we argue that claims of misrepresentation are constitutive to the process of claim-making. The inclusion of negative claims as representative's performance, as a strategy of persuasion and reframing of the political discourse, is necessary to understand the varied effects of this political style. The recognition of negative claims as part of the process of representationacting, staging, and framing-can illuminate how the role of makers becomes prominent, and claims are affected by audiences. We show that this audience effect goes beyond the mutual and democratic influence envisaged by Saward, since the receptiveness of the audience to negative claims can influence the performance of representatives.

Misrepresentation has always been part of the history of representation. The claims of misrepresentation are ever-present-in partisan conflicts expressed through rival discourses created to discredit and deceit the opponent or the public-and have always played a role in modern political representation (Disch, 2011). Moreover, as the notion of inclusion depends on what is excluded, so Pitkin's definition of representation depends on the inverse understanding of what is not represented. Misrepresentation is inevitable, even when we represent ourselves (Alcoff, 1991). Thus, the theory of representation needs to develop categories to understand the dynamics of misrepresentation, especially when they are strategically explored by (populist) actors to discredit their opponents, the system and representative democracy as a whole.

Until now, the emergence of claim makers asserting misrepresentation has been associated with the malfunctioning of representative democracy (Saward, 2010). There is a disagreement about their impact on the political system. Pierre Rosanvallon sees the gap between democratic society (abstract) and democratic sovereignty (personified as will) as a 'constitutive aporia' - the necessary distance between the figuration of reality and reality itself (Rosanvallon, 2008). The incomplete character of representation in the figuration of the people opens up spaces for the democratic contestexpressed by claims of misrepresentation (Saward, 2006, 2010, 2017). For Rosanvallon (2008), the exercise of counter-politics is an essential part of modern democracy and complementary to representative democracy. There are many aspiring political parties and advocacy groups seeking to challenge the status quo to accuse representatives or other advocacy groups of not representing their constituency. Although negative power is unpolitical in its forms, it is not anti-political in its outcome (Taggart, 2018; Urbinati, 2010, p. 70).

Contrary to Rosanvallon, Urbinati (2010) suggests that unpolitical expressions generate dispassionate judg- ment that can have both positive and negative effects on representative democracy. The positive effect is the potential for revitalization; the negative effect is the risk of bypassing the legitimate authority of citizens' suffrage (Urbinati, 2010, p. 75). Although Urbinati (2019) favors openness to contestation instead of interruption and containment of the democratic practices, she is skeptical about the growing openness of spaces for criticism of the representative government, which establishes cloven and negative citizenship with little room for exercising equal political power.

The emphasis on performance exalts the role of the speaker (maker/subject) and derives legitimacy from appeal/acceptability. On the one hand, it reinforces inequality in the process of claim-making, since the good performer has more chance to attract an audience, and people are subjects of opinions, not will. On the other hand, claims become audience-dependent, impacting how they are framed and for which purpose.

Thus, it is essential to analyze the effect of audiences. Some scholars have highlighted the impact of audience attention in shaping the public debate (De Wilde, 2019; Michailidou \& Trenz, 2013; Moffitt, 2016). Studying populist leaders, Moffitt (2016, p. 47) differentiates between the audiences that populist leaders seek to rely on. Therefore, representation is not only for an audience (those who should receive and evaluate the image of them offered by the subjects), but also oriented to an audience. Politics has become more stylized, spectacular and mediatized, a point made years ago by Manin (1997), requiring claims more appealing to audiences, including their constituents, but also the government, donors, and journalists (De Wilde, 2019).

Political representation is audience-driven, which means that claims are constructed based on the filter of the audience. In Saward's performative understanding of representation, representatives must shape-shift their performance constantly to convincing the audience (Saward, 2014). However, considering only positive claims, Saward leaves unaddressed the issue of incentives derived from the audience to produce negative claims, since framing discourses based on crisis and misrepresentation has a strong appeal and taps into familiar frameworks. Claim-makers are not only questioning misrepresentation because of its natural incompleteness and intention to improve representative performance, but also utilize crisis as a tool against the status quo (Moffitt, 2016). In other words, a crisis arises as a result of a mismatch between the political system and political demands (Ankersmit, 2002), and as a product of claims of misrepresentation that overemphasize the void between representatives and the represented in order to gain political attention.

To unpack claims of misrepresentation, we incorporate important insights about the risks involved in negative claims, such as increasing skepticism and extremism, from the literature on the interplay between populism and democracy. The incorporation of this specific 
strain of populism literature enables us to conceptualize claims as rhetoric and strategically constructed by the makers to audiences (Hartleb, 2015; Kaltwasser, 2014), as communicative strategy of populist leaders and political style that is performed, enacted and embodied by actors across the world (Moffitt, 2016). Taggart's notion of 'unpolitics' as a populist confrontation with representative democracy, shows how populism plays up popular sovereignty while downplaying other democratic features such as rights and the rule of law (Taggart, 2018, p. 80). Populism represents a fundamental and profound ambivalence about polity, politics, and policies in a representative democracy.

The value and distinctions in this field study are vast, but to characterize positive and negative claim, we take three elements. First, it helps to understand how claimmakers construct themselves as challengers by identifying an antagonist, such as representative democracy, political elites, or immigrants (Moffitt, 2016); and by creating and exploiting a cleavage between us and them that is possible due to their identification as outsiders (Barr, 2009; Schedler, 1996). The definition of outsiders varies according to their position in the political system: e.g., from outside, such as civil society actors with renewed discourses of the political system, or from "inside", politicians that take advantage of their marginal location to criticize political establishment (Barr, 2009; Rodríguez Andrés, 2016). Claims of representation are always partial and open to the political contestation (Saward, 2010). Claims of misrepresentation, however, go further. Claims of misrepresentation exhibit characteristics of antagonistic conflicts, a claim to be universal, national, and sometimes hegemonic, with implications to think about (representative) democracy (Mouffe, 2013).

Second, in order to persuade others, claimants present causes and targets of misrepresentation: representative democracy and the political system (polity), politics (established parties, and/or establishment) or policies (cf. Hartleb, 2015). While in the actual political discourse, these categories are overlapping, it is crucial to conceptually distinguish what is being contested in order to understand how claims of misrepresentation affect representative democracy. Anti-establishment politics present the crisis as a diagnosis, and its cure is less in a change of policies, and more in the field of politicschanges in personnel, accountability and citizen participation (Barr, 2009, p. 37; Buštíková \& Guasti, 2019). The challenges to the polity are profound, as populism revels in its transgression of existing norms and the repudiation of representative politics as a process for resolving conflict (cf. Taggart, 2018, p. 81).

We argue that more empirical research is needed to grasp the variety of claimed 'causes' of misrepresentation and distinct claims of representation. We argue that claims of misrepresentation are often a precursor to claims of representation: claimants use the claim of misrepresentation to eradicate the existing (formal) linkage between rival representative and the constituency, in order to posit themselves as the 'true' representative. Thus, to fully understand the claim of representation in the time of growing populism, we ought to also focus on the claim of misrepresentation.

Third, as claims of misrepresentation are often a precursor to positive claims or discourses, it invokes crisis to mobilize support and demand immediate action (cf. Moffitt, 2016; Mudde \& Kaltwasser, 2011). The solutions to the problem of misrepresentation include the removal of the opponent or enemy, new types of representatives and participatory politics, adopting a more direct linkage between (populist) leaders and the people (Barr, 2009; Buštíková \& Guasti, 2019; Taggart, 2018). In our cases, the performative appeals to the ordinary man, the people or the general interest is not always followed by an explicit demand of an alternative representative or even by the creation of a populist leader (cf. Buštíková \& Guasti, 2019). Instead, the role of claim makers becomes prominent, and claimants are 'only' discrediting the existing policies and politics, including forms and subjects of representation (De Wilde, 2013).

In summary, we define the claim of misrepresentation as claim maker presents new demands by disputing the existence of a linkage between established representative and the claimed constituency (1: strategy), by identifying a cause of misrepresentation attacking existing policies, politics, and/or polity (2: persuasion): and, sometimes, by establishing itself as the new representative or proposing another solution (3: reframing).

The majority of claims of misrepresentation both present new political demands, while challenging the legitimacy and authority of the elected representatives regarding what they do (policies), how they do it (politics) and for whom they do it (polity). Claims of misrepresentation are ambiguous, rather than intrinsically democratic (Rosanvallon, 2008) or adversarial to democracy (Urbinati, 2010). They are present in the right and left spectrum, and can be democratic or undemocratic, inclusionary or exclusionary (Mudde \& Kaltwasser, 2011; Taggart, 2018).

Focusing on claims of misrepresentation opens up new possibilities to analyze representation, while maintaining the performative understanding that representative claims are constructed to persuade and produce an effect on the audience (Saward, 2017). It is essential to point out that there are not only cooperative but also competitive dynamics that can distinctly affect the political system (De Wilde, 2013).

\section{Operationalization of the Cases and Methodological Remarks}

\subsection{Case Selection and Comparability}

Our analysis aims to test the generalizability of the concept-the "claim of misrepresentation' (Bunce, 1998, p. 206)-by focusing on two singular events that represent ruptures of representative democracy. Testing the 
applicability of our concept in the Global North and the Global South enables us to highlight the comparability of the challenges facing representative democracies, to observe variation in representative claims-positive and negative-and to offer claims of misrepresentation as a useful analytical concept. We do not focus on the effects of these ruptures, the reasons why claims of misrepresentation arise, their salience or impact.

In many ways, our cases could not be more different. Germany is an established democracy in the Global North and Brazil is a transition country in the Global South. We focus on two types of actors, elected representatives and self-selected civil society representatives. Our arenas are the parliament during plenary sessions and online fora. We seek a deeper understanding of the moments of rupture in which (populist) insurgents question the legitimacy of the existing order along three dimensions: policies, politics, and the polity.

Following Sartori (1991) and Tarrow (2010), we believe there is a value in comparing very different cases as an 'intermediary step in theory building' (Tarrow, 2010, p. 245). Testing the extent to which in two very different countries and arenas, different actors use claims of misrepresentation to challenge the legitimacy of the existing political order enables us to both test and refine our theory (cf. Collier, 1991; Lieberman, 2005). Despite the differences in our cases, we find similar claims portraying misrepresentation, identifying the subject misrepresenting, and (sometimes) proposing solutions.

Finally, despite the distinctions between claims made in Facebook pages, which presuppose the possibility of edition and deletion, compared to speeches in parliament, it is necessary to consider two features. First, a qualitative analysis of claims has shown that plenary parliamentary debates-expected to be superior considering the opportunity to speak for minutes-sometimes feature lower quality of representative claims than mass media (De Wilde, 2019). Second, considering our framework that claims are audience-driven, even discourses in parliaments are performed and theatrically constructed to appeal to the audience.

\subsection{Operationalization and Method}

We are comparing the presence of claims of misrepresentation in Brazilian debates, before and during the presidential impeachment between 2014 and 2016, with those in Germany during the first six months of the AfD in the German Parliament 2017 and 2018. We find a high number of claims of misrepresentation, a significant degree of variation in the combination of positive and negative claims, and varying degrees of focus on policies, politics, and polity. Both teams used three comparable categories to analyze the material:

1) Claim makers (who speaks);
2) Subject (who acts/does not act/should act on behalf of the claimed constituency);

3) Claimed Constituency (on whose behalf claimmaker to speak).

The Brazilian case was analyzed using indirect discourses made by five civil society organizations proimpeachment in their Facebook Fan Pages. The data was collected between 17 December 2016 and 5 December 2017, using Netvizz Facebook's API. The posts collected from each civil society group were organized as a .csv database. The data encompasses the claims of misrepresentation presented from 1 November 2014, shortly after the re-election of Dilma Rousseff, until 31 August 2016, when the impeachment trial took place at the Brazilian Senate. We have collected posts made by the managers of the public pages, in a total of 45,721 posts, and performed a sample of $10 \%$ of this material on $R$ Statistical Software, sorted by year and month of creation. The content of posts was analyzed using Atlas.ti Software. The unit of analysis corresponding to each message posted, including images, videos, or links to external pages. A total number of 2,970 claims were identified from 4,574 posts published on Facebook's pages. Claims of misrepresentation were the most dominant, making up $87.9 \%(2,611)$ of the overall claims' sample. Claims of representation made up $12.1 \%$ (359). A total number of 1,524 posts $^{1}$ were classified as nonclaims, concerned with daily activities carried out by the organizations, and calls for mobilizations in favor of impeachment.

The German case was analyzed using 34 full shorthand stenoprotocols from the plenary meetings of the German Bundestag between 24 October 2017 and 18 May 2018 (first six months of the current term, the first in which AfD is present). A total number of 2,259 claims were identified from statements by MPs of the AfD. Both formal and informal speech was analyzed (formal speech is an address by an MP, while informal speech is an interjection by an MP during the address of an MP from opposing party). Claims of misrepresentation made up $66.4 \%(1,500)$ of the overall sample $(2,259$ claims $)$ and were the most dominant form of claim-making by the MPs of the AfD for Germany (claims of misrepresentation were dominant category both among formal and informal forms of speech). Claims of representation made up $6.7 \%$ of the sample (151). Excel and Atlas.ti were utilized to analyze the claims.

\subsection{Unit of Analysis and Application}

Our unit of analysis corresponds to one claim-usually a sentence or part of a sentence identified by the coder. Concerning Facebook pages, one post equals one sentence. In German parliamentary debate, one discourse may contain various sentences. A claim of misrepresen-

\footnotetext{
${ }^{1}$ Some posts were not identified because their content was no longer available on the Internet. In the Revoltados ONLINE (ROL) Facebook Page, 235 posts were excluded from the analysis because they neither contained the text nor the link to the content.
} 
tation may contain all or some of the elements, identification of an antagonist or a subject that misrepresent, a cause of polity, politics, and policy related to different themes, and a solution. We will use an example to make this clear-one from Brazil and one from Germany (see Table 1).

\section{Brazilian Case of Impeachment: Claims of Misrepresentation without Representation?}

The impeachment of the Brazilian president, Dilma Rousseff, is an interesting phenomenon to study claims of misrepresentation in a scenario of political representation and party crisis. Since her re-election in 2014, Dilma Rousseff had been targeted with many criticisms. After a period of instability, loss of control of the political dynamics in Congress and several impeachment's requests in parliament, Eduardo Cunha, then-Speaker of the House, initiated the impeachment proceedings in December 2015, which concluded on 31 August 2016. Many factors explain this decision and the Brazilian political crisis. Here, we focus on the strategy of some civil organizations that, in claiming the misrepresentation of the president and her political party, have contributed to the impeachment and the intensification of an unprecedented political crisis.

Despite the large number of civil society organizations involved in the impeachment campaign, other studies (Dias, 2017; Tatagiba, Trindade, \& Teixeira, 2015) and news articles indicate that five groups have led the mobilization process: Movimento Brasil Livre (MBL), NasRuas Movement, Movimento Endireita Brasil (MEB), Vem Pra Rua Brasil (VPR) and Revoltados ONLINE (ROL). The sample analyzed contains 1,282 MBL messages, 1,036 from NasRuas, 443 from MEB, 395 from VPR, and 1,418 from ROL.

In a short period, pro-impeachment groups made a variety of claims, based on an intensified presence in the Facebook pages. ${ }^{2}$ They are located in the right-wing spectrum, defend economic liberalism, and consider themselves non-partisan organizations. Despite similarities, their ideological profiles vary. MBL was founded by young leaders in 2013, while NasRuas (established in 2011) and ROL (established in 2000) ${ }^{3}$ are run by liberal professionals previously engaged in anti-corruption groups. MEB, on the other hand, was created in 2006 by entrepreneurs and liberal professionals to include rightwing people in the political system. Some of them have already disputed elections or worked in elected administrations (Dias, 2017). VPR was founded by entrepreneurs, who mobilized in the face of Rousseff's impending reelection in 2014, as they tried to prevent it. All proimpeachment groups are outsider groups anxious for change, but they do not share the same political project or strategies to accomplish their goals (cf. Dias, 2017; Rodríguez Andrés, 2016). During the impeachment campaign, some-NasRuas and ROL-claimed more conservative and aggressive agendas. Other, such as VPR, could be identified as center-right. Nonetheless, all groups took the growing public rejection of the results of the economy, corruption scandals, government's actions or disputes over moral issues-to position themselves as relevant political actors pursuing their agenda.

The pro-impeachment claim-makers systematized dissatisfactions and proposed narratives that strategically void the existing linkage between the president and the people, and blame Dilma Rousseff and her government (608 claims), Workers' Party-PT (561), the expresident Luís Inácio Lula da Silva (434), and other politicians from PT and other parties (286) for the political crisis. Some claims do not present a clear subject of misrepresentation, and are only related to a cause. Among the claims of misrepresentation $(2,611), 70.5 \%$ were focused on disagreements on politics, $19.9 \%$ on policies and $7.4 \%$ on the polity. A distinct type of claim has emerged in the online sphere, namely, the misrepresentation of mass media (2.2\%), especially "Folha de São Paulo" and "Rede Globo" , due to the organizations' evaluation of the poor quality of journalistic coverage of the political crisis. Concerning the claims of representation (359), 58.8\% were focused on proposals on politics, $34.8 \%$ on policies, and $6.4 \%$ on the polity.

During two years of intense political turmoil, these organizations explored the crisis and appealed to politics as the leading cause of misrepresentation. However, the rejection of politics does not affect the whole establishment or all political parties. The problem is specific to the PT-that was 14 years in power of the Federal government-and its leaders. Corruption, theft or conspiracy represents $24 \%$ of the universe of 2,611 claims of misrepresentation. The second cause of misrepresentation on politics is also related to corruption: the politicians' attempt to discredit Car Wash Investigation (an ongoing criminal investigation by the Federal Policy of Brazil), delay or obstruct justice (10\%). They also appeal to ideological justification and embrace conspiracy theories. This simplifies the complex reality, such as the need to oppose socialist, communist, Bolivarian or leftist ideas (9\%), and persuades the public about the inevitability of impeachment (Taggart, 2018).

The performative process of persuasion assumes different forms of accusation and disputed narratives regarding policies. On the one hand, they blame the government's policies for the economic crisis, growth of the unemployment rate and raising taxes, especially $\mathrm{MBL}$ (6.7\% of claims of misrepresentation). On the other, or-

\footnotetext{
2 They have different presence on Facebook considering the number of followers of the Page in the time of data collection: MBL (1,729.352 likes); ROL $(2,116)$; VPR (1,476.453); NasRuas $(366,287)$, and MEB $(649,759)$.

${ }^{3} \mathrm{ROL}$ is the oldest group, and it was created to combat pedophilia on the internet. After the huge wave of protests in 2013 , the group engaged in the anti-corruption campaign.

${ }^{4}$ Folha de São Paulo is one of the country's main newspaper with the largest circulation and influence, and Rede Globo is the largest media conglomerate in Brazil and one of the largest media company in the world.
} 
Table 1. Examples of analyzed claims of misrepresentation in Germany and Brazil.

\begin{tabular}{|c|c|c|c|c|}
\hline \multirow[t]{2}{*}{ Category } & \multicolumn{2}{|l|}{ Germany } & \multicolumn{2}{|l|}{ Brazil } \\
\hline & Quotation & Explanation & Quotation & Explanation \\
\hline \multirow[t]{2}{*}{$\begin{array}{l}\text { Policy } \\
\text { disagreement } \\
\text { on policy. }\end{array}$} & $\begin{array}{l}\text { Since there is no } \\
\text { German government, } \\
\text { I am convinced that } \\
\text { first; we have to shape } \\
\text { foreign policy in our } \\
\text { interest because no } \\
\text { one else does it for us. }\end{array}$ & $\begin{array}{l}\text { The first part } \\
\text { insinuates that the } \\
\text { current government } \\
\text { does not represent } \\
\text { German interests; the } \\
\text { second part is } \\
\text { disagreement on } \\
\text { policy. }\end{array}$ & $\begin{array}{l}\text { Dilma deliberately } \\
\text { destroyed the } \\
\text { economy and created } \\
\text { the crisis to continue } \\
\text { in power. Dilma should } \\
\text { move out (MBL). }\end{array}$ & $\begin{array}{l}\text { Dilma does not } \\
\text { represent. There is a } \\
\text { claim of } \\
\text { misrepresentation on } \\
\text { policy-economy- } \\
\text { and a solution has } \\
\text { been presented: Dilma } \\
\text { out. }\end{array}$ \\
\hline & $\begin{array}{l}\text { Therefore, I urge you } \\
\text { to finally make sound } \\
\text { programs for the } \\
\text { people in this country } \\
\text { as well as for the } \\
\text { migrants. }\end{array}$ & $\begin{array}{l}\text { Disagreement on } \\
\text { policy, but } \\
\text { simultaneously claim } \\
\text { of misrepresentation- } \\
\text { government parties } \\
\text { represent neither } \\
\text { (German) citizens, nor } \\
\text { the migrants. }\end{array}$ & $\begin{array}{l}\text { There is a serious } \\
\text { socioeconomic } \\
\text { imbalance in Brazil, } \\
\text { after more than a } \\
\text { decade of a } \\
\text { government of } \\
\text { misleading } \\
\text { propaganda. The } \\
\text { unemployment } \\
\text { appears as the most } \\
\text { powerful indicative of } \\
\text { this. Every minute } \\
\text { seven workers are } \\
\text { fired in Brazil....We are } \\
\text { under the domination } \\
\text { of the same cadre of } \\
\text { corrupt and } \\
\text { incompetent } \\
\text { politicians (NasRuas). }\end{array}$ & $\begin{array}{l}\text { Corrupt politicians do } \\
\text { not represent. There is } \\
\text { a claim of } \\
\text { misrepresentation on } \\
\text { economic issues- } \\
\text { unemployment. } \\
\text { Simultaneously, they } \\
\text { claim } \\
\text { misrepresentation on } \\
\text { politics-misleading } \\
\text { and corrupt politicians. } \\
\text { No solution or } \\
\text { redefinition is clearly } \\
\text { articulated. }\end{array}$ \\
\hline \multirow[t]{2}{*}{$\begin{array}{l}\text { Politics } \\
\text { disagreement } \\
\text { with estab- } \\
\text { lished/ruling } \\
\text { parties on how } \\
\text { politics is run. }\end{array}$} & $\begin{array}{l}\text { You have said a lot } \\
\text { about yourself about } \\
\text { your parliamentary } \\
\text { and democratic } \\
\text { habits. }\end{array}$ & $\begin{array}{l}\text { Attacking MP of an } \\
\text { established political } \\
\text { party, MP of AfD } \\
\text { insinuates established } \\
\text { parties are } \\
\text { undemocratic. }\end{array}$ & $\begin{array}{l}\text { Does anyone have any } \\
\text { doubts that the bandit } \\
\text { Lula looted Brazil } \\
\text { through the BNDES } \\
\text { (National Bank of } \\
\text { Development)? Billions } \\
\text { have been diverted on } \\
\text { behalf of the political } \\
\text { power project of his } \\
\text { party. } \\
\text { \#SomostodosMoro; } \\
\text { \#ImpeachmentJá } \\
\text { (NasRuas). }\end{array}$ & $\begin{array}{l}\text { Lula does not } \\
\text { represent. He is } \\
\text { treated as an enemy, a } \\
\text { thug. Corruption is the } \\
\text { cause of } \\
\text { misrepresentation. As } \\
\text { a solution, they } \\
\text { support Judge Sergio } \\
\text { Moro-from Car Wash } \\
\text { Investigation-and } \\
\text { demand Dilma's } \\
\text { impeachment. }\end{array}$ \\
\hline & $\begin{array}{l}\text { They (citizens) were } \\
\text { even lied to; to mask } \\
\text { the enormity of } \\
\text { uncontrolled } \\
\text { immigration, the myth } \\
\text { of skilled labor } \\
\text { immigration became } \\
\text { one of the founding } \\
\text { lies of the old parties } \\
\text { shortly after the } \\
\text { opening of the } \\
\text { border. }\end{array}$ & $\begin{array}{l}\text { An accusation of the } \\
\text { established parties of } \\
\text { lying to citizens (and } \\
\text { also disputing } \\
\text { government policy). }\end{array}$ & $\begin{array}{l}\text { We are in mourning, } \\
\text { because of so much } \\
\text { that the Workers" } \\
\text { Party (PT) has stolen } \\
\text { from Petrobrás. } \\
\text { \#PTOUT! (MEB) }\end{array}$ & $\begin{array}{l}\text { Workers' Party does } \\
\text { not represent. The } \\
\text { cause is corruption in } \\
\text { Petrobrás. The solution } \\
\text { is the removal of PT. }\end{array}$ \\
\hline
\end{tabular}


Table 1. (Cont.) Examples of analyzed claims of misrepresentation in Germany and Brazil.

\begin{tabular}{|c|c|c|c|c|}
\hline \multirow[t]{2}{*}{ Category } & \multicolumn{2}{|l|}{ Germany } & \multicolumn{2}{|l|}{ Brazil } \\
\hline & Quotation & Explanation & Quotation & Explanation \\
\hline \multirow[t]{2}{*}{$\begin{array}{l}\text { Polity } \\
\text { disagreement } \\
\text { on the definition } \\
\text { of polity. }\end{array}$} & $\begin{array}{l}\text { An incredible lack of } \\
\text { solidarity with your } \\
\text { people! }\end{array}$ & $\begin{array}{l}\text { Insinuates that social } \\
\text { democrats do not } \\
\text { represent the people. }\end{array}$ & $\begin{array}{l}\text { The people have not } \\
\text { been heard. By } 52 \\
\text { votes to } 27, \text { Edson } \\
\text { Fachin was approved } \\
\text { by the Senate to be } \\
\text { the next Minister of } \\
\text { the Federal Supreme } \\
\text { Court. It will be a long } \\
18 \text { years that we will } \\
\text { have to endure the } \\
\text { partisan rigging of the } \\
\text { Judiciary (ROL). }\end{array}$ & $\begin{array}{l}\text { Senate does not } \\
\text { represent. The cause is } \\
\text { related to the lack of } \\
\text { legitimacy of ministers' } \\
\text { choice, and the lack of } \\
\text { autonomy of the } \\
\text { Supreme Court. No } \\
\text { solution. }\end{array}$ \\
\hline & $\begin{array}{l}\text { An activating family } \\
\text { policy, as demanded } \\
\text { by us, would be a } \\
\text { priority instead of } \\
\text { exchanging our } \\
\text { people. }\end{array}$ & $\begin{array}{l}\text { The real speech } \\
\text { segment is a mixture } \\
\text { of more elements-a } \\
\text { claim of } \\
\text { representation } \\
\text { ('activating family } \\
\text { policy' claim of } \\
\text { misrepresentation on } \\
\text { polity-the } \\
\text { government is } \\
\text { exchanging its citizens } \\
\text { by migrants). }\end{array}$ & $\begin{array}{l}\text { The National Congress } \\
\text { of Workers' Party is a } \\
\text { freak, with a Bolivarian } \\
\text { mentality. We cannot } \\
\text { let they transform us } \\
\text { in a new Venezuela. } \\
\text { Say not to communism } \\
\text { (VPR). }\end{array}$ & $\begin{array}{l}\text { Workers" Party does } \\
\text { not represent. The } \\
\text { polity } \\
\text { misrepresentation is } \\
\text { related to their } \\
\text { intention to change } \\
\text { the Brazilian political } \\
\text { system to communism. }\end{array}$ \\
\hline
\end{tabular}

Notes: Movimento Brasil Livre (MBL); Movimento Endireita Brasil (MEB); Revoltados ONLINE (ROL); Vem Pra Rua Brasil (VPR). Source: Analysis of the German and Brazilian cases.

ganizations claimed the tenets of economic liberalism, including the defense of privatization and entrepreneurship, and the expansion of individual freedom (4.4\%). Other problems raised are related to education, health, and public security policies.

In respect to polity, the primary disagreement was about the constitutionality and legality of Dilma's impeachment (8.1\%). Although impeachment is previewed legally, during the process, there were juridical doubts if Dilma Rousseff had committed a crime of responsibility. Pro-impeachment organizations intensely defended the legality of impeachment and its use as a solution for the political crisis. The Federal Supreme Court was also a target (4\%). According to the posts on Facebook, their decisions violated the division of powers and politically interfered in impeachment procedures.

The organizations sought primarily to encourage rejection of the political scenario rather than presenting positive claims. The constituencies are only implicit and appear through the discourses that embody the desires of Brazilian people or the nation. Among the total of claims of misrepresentation and representation $(2,970)^{5}$, Dilma's impeachment was the sine qua non condition for the cure of misrepresentation (30\%), followed by argu- ments of "PT Out" (21\%) and the demand for Lula's imprisonment (11.4\%). One notable difference to Saward's original representative claims framework is that although they are both presenting political demands and making assertions about something-there are positive claims about politics and policies (Castiglione, 2017), they are not portraying themselves as representatives or rarely pointing out someone as the representative. They are makers without subjects and indicate other representatives only to blame and discredit them (cf. De Wilde, 2013). The judge Sérgio Moro was the most cited as the potential representative ( 92 claims of 359 claims of representation), especially by NasRuas and ROL, and Michel Temer (33), the vice-president who took office after Dilma withdrawal of the post in May 2016 during impeachment procedures, was mentioned by NasRuas and MBL.

Although it is challenging, and it is not our intention to evaluate the impact of these discourses on political crisis, it is possible to affirm that these organizations act as a trigger to the crisis. They created a discursive political environment of complete misrepresentation of the politics, with clear identification of a specific enemy-the PT, and its leaders, that have contributed to the result of impeachment. They were also responsible for mobilizing

\footnotetext{
${ }^{5}$ The percentage of solutions was calculated among the total of claims (positive and negative) since in distinct posts it was common to share hashtags or requests for impeachment, \#PTOUT, and Lula's imprisonment.
} 
Brazilian people against the government. Among the total of 1,524 of Facebook posts identified as non-claims, $1,030(67.6 \%)$ were related to call for mobilizations, that led millions of people on the street to protest between November 2014 and August 2016. Finally, although they initially do not present themselves as alternative representatives, the claims of misrepresentation were precursors of positive claims presented post impeachment. After all, their strategic appeal to the audience regarding the need for an immediate change of the political landscape was crucial for gaining future electoral support. The five organizations launched or support candidates in 2016 municipal elections, and their main leaders participated in 2018 national elections. NasRuas, MBL, and ROL elected federal deputies ${ }^{6}$, who were among the main articulators of the organizations' Facebook pages.

\section{German Case AfD in the German Bundestag: The Combination of Claims of Representation and Claims of Misrepresentation}

In this case study, we have focused on claims raised by the AfD in its first six months in the German Bundestag (24 October 2017-18 May 2018). AfD is the first radical right political party, which successfully entered the German Parliament since WWII (Arzheimer \& Berning, 2019). Its main appeal is anti-establishment (politics), anti-immigration (policy), and anti-Muslim (polity). We coded 3,464 pages of documents, identified 2,259 claims, of which $1,500(66.4 \%)$ were claims of misrepresentation and $6.7 \%$ (151) claims of representation. Of the claims of misrepresentation, approximately $50 \%$ focused on disagreements on policy, $30 \%$ were focused on disagreements on politics and approximately $20 \%$ on the polity.

Regarding policy, AfD focused on several issues: migration, monetary policy, and defense policy. The rejection of migration policy dominated all AfD speeches. In every formal speech by an AfD member of parliament (MP) regardless of the main topic, rejection of migration policy of the Merkel government was included. The criticism of the monetary policy was the second most frequent policy disagreement and represented the expression of AfD's Euroscepticism. It portrays the Markel's government as overreaching and setting the German taxpayers up for failure. It also portrays the German government as giving up sovereignty both to the European Commission and to France. The third most common policy issues criticized by the AfD were foreign military mission (and as a proxy NATO). In these claims of misrepresentation, AfD is critical towards the government-accusing it of underfunding the military, betraying German soldiers and risking their lives by sending them to foreign missions underequipped. On a more general level, this critique questions the meaning of military missions as such and calls for the focus on internal security instead.
The AfD portrays refugees as a security risk, as a drain on state resources, and more generally as a threat to German culture and the way of life. The refugees are often reduced to Muslims and portrayed as a particular danger to German women (especially following medialized cases of attacks on women by migrants). After an attack of a young Muslim on a Jewish pupil in Berlin in Spring 2018, AfD called for a discussion on antisemitism in the German Bundestag. In this one-hour debate Aktuelle Stunde ('Current Issues') refugees and Muslims (used interchangeably) were portrayed as the primary source of anti-Semitism in contemporary Germany. The AfD, which itself has strong anti-Semitic elements, portrayed itself as the defenders of the Jews in Germany against the danger posed by anti-Semitic refugees.

In respect to policy, it is important to say, that as a small oppositional party, AfD's actual impact on policy is non-existent. Other parties support none of the AfD proposals, and AfD rarely supports bills or resolutions by other political parties. An exception is the support of the AfD neoliberal wing for some proposals by the oppositional (and neoliberal) Free Democratic Party (FDP). However, given that both AfD and FDP are in opposition, none of their proposals or resolutions won a majority vote on the floor of the German Parliament.

The fact that other parties consistently refuse AfD proposals fuels the claims of misrepresentation on politics. Here the AfD portrays itself as the 'true voice of the people' and accuses the established parties (Altparteien) of betraying the will of the people. Interestingly, most critique does not target the government, Chancellor Angela Merkel, or her Christian Democratic Union (CDU/CSU). Instead, the primary target of the claims of misrepresentation are the Social Democrats (SPD).

AfD accuses SPD of betraying the workers and portrays itself as the 'new workers party.' This is a strategic move on the part of the AfD-a strategy based on the calculation that future votes for AfD will come from the current SPD voters' disenchantment with the SPD's shift towards the center and embrace of European integration and multiculturalism. In this way, the AfD seeks to exploit the gap between the SPD elite (more cosmopolitan) and the electorate (more communitarian). The AfD does not see similar potential for voter switch on the centerright, thus the focus of accusations of misrepresentation on politics on the SPD or target all parties as a wholethus portraying the current system as corrupt (morally not economically).

The claims of misrepresentation focused on polity represent attempts at redefining who constitutes polity (exclusion of naturalized citizens, holders of double citizenship) and the rejection of values (gender equality, religious freedom, integration). In these claims, the AfD portrays itself as the representative of the nation, national identity, sovereignty, German language, German history, German constitution, traditions, justice, democracy (in

\footnotetext{
${ }^{6}$ The MBL has changed its political strategy since 2016 . They have launched 46 candidates, elected six municipal representatives in different Brazilian cities and states, and elected in 2018 three federal deputies. See Movimento Brasil Livre (n.d.).
} 
particular direct democracy), fairness human/women's rights, defender of religious freedom (for Jews and Christians, not for Muslims). It accuses other parties of betraying these norms, value, and constituencies.

In terms of constituency, we identified an internal split within the AfD: (a) neoliberal group of MPs focused on criticism of Euro, the EU, European monetary policies, presents itself as the representative of German taxpayers, German enterprises, (and normative schemes such as nation, national sovereignty, national identity); (b) a group of MPs who see AfD as the new worker's party and sees itself as the representative of specific groups which the Merkel rule "betrayed" and "left behind" these are most often soldiers, ordinary working German families, small farmers, small and medium enterprises, car owners. There is a deep division within the AfD on economic policy, and the (only) issue that unifies these two factions within the AfD is the rejection of the refugees and the Merkel refugee policy. Given the significant differences in AfD support in the old (former Federal Republic of Germany) and the new German states (former German Democratic Republic), it is interesting that the underdogs (those left behind) are rarely portrayed as the 'East Germans.'

In respect to polity, some AfD MPs also embrace a conspiracy theory that the migration policy is a plot by the establishment, which has lost the support of 'true Germans' to create new electorate by granting citizenship to migrants and refugees. This conspiracy theory has been circulating among the radical right in Germany for some time, but it is now presented on the floor of the German Parliament. This discourse strongly resonates with those of the white supremacists in the USA, who often chant 'you will not replace us' (alluding to minorities).

The AfD case shows a campaign strategically designed and directed to claim the misrepresentation of the people not only by the government, but by the establishment as a whole (both parties in power and the opposition-especially the Greens). The AfD discourse is populist and Eurosceptic. It combines both right-wing populism (portraying people as a nation, exclusionary) and left-wing populism (speaking on behalf of those 'left behind').

The strategy of the AfD is to present the diagnosisthe linkage between the established parties and 'the (German) people' is broken, because the establishment is morally and politically corrupt and misrepresents the people in terms of policies, politics, and polity; and the cure-to present itself as the new representative of the people. To do so, the AfD uses the claims of misrepresentation as a precursor to its claims of representation.

\section{Conclusion}

The representative turn in democratic theory has rapidly changed the way representation is defined and comprehended. Also, the recuperation of a constructivist di- mension of representation presents in different traditions over time has generated three significant shifts (1) from political will to political judgment; (2) from constitutional to constitutive character of representation; and (3) from electoral to non-electoral representation. Michael Saward (2006, 2010, 2014), the most cited author in this redirection, alerts us to analyze representation based on its performative role, instead of on the static model based exclusively on elections.

Despite many advantages of the claim perspective, we argue that it does not address the negative claims or offer clear direction to assess them. To perform this task, we suggest to incorporate contributions from Rosanvallon (2008) and his evaluation on the positive effects of claims of misrepresentation-counter-politics; Urbinati's concern of the unpolitical (2010), and the populism literature on 'unpolitics' - the enemy, the appeal to the "people" and the presence or not of a positive claim (Taggart, 2018).

We consider claims of misrepresentation to be ambiguous regarding their effects on representative democracy, and strategically employing persuasion and performance-presenting critiques of policies, politics, and polity, in order to demand changes-and (in some cases) highlight the broken linkage between elected representatives and the people, and potentially to establish themselves as the new representatives.

We identify both similarities and differences between our two cases. The nature of our cases leads to different claim makers -in the German case, these are members of parliament for the AfD (the marginalized outsiders), in the Brazilian case, the makers vary (outsiders of the political system), and there is no indication of explicit subjects. As for objects, we find similarities - both cases show the populist division between the corrupt elite and the 'pure people' (cf. Mudde \& Kaltwasser, 2011). The causes of the misrepresentation are the moral (German case) and both moral and financial (Brazilian case) corruption of the political establishment (cf. Taggart, 2018).

Claim makers present new demands, but also challenge existing policies, politics, and polity. However, the different actors and political contexts influence the primary focus in the misrepresentation of policies, in Germany, and politics, in Brazil. Both cases present a strong appeal to the political crisis to convince the audience, but have different ways to address the problems of misrepresentation.

While AfD performatively presents itself as the new representative of 'the people', pro-impeachment organizations are makers that construct neither the constituency, nor the subject. With respect to exclusionary versus the inclusionary character of the populist discourse, both cases can be described as exclusionary, in Brazil of specific political actors and parties, and Germany of Muslims and refugees (cf. Arzheimer \& Berning, 2019; Mudde \& Kaltwasser, 2011). The effect of these claims of misrepresentation will largely depend on 
the reaction of the established parties-if they will focus on the message, not on the messenger-addressing the grievances of the people, rather than demonizing the ascending political opponents.

\section{Acknowledgments}

We thank the DFG and ANR for their kind funding of the research project "(New) Political Representative Claims: A Global View (France, Germany, Brazil, India, China)." We also thank the three anonymous reviewers for their comments and recommendations. The Brazilian, sample data used in this article were part of the Master Dissertation defended by Tayrine Dias in the Political Science Institute of the University of Brasilia. We are grateful to her for sharing her data, which was recoded and analyzed by the authors to understand claims of misrepresentation.

\section{Conflict of Interests}

The authors declare no conflict of interests.

\section{References}

Alcoff, L. (1991). The problem of speaking for others. Cultural Critique, 20, 5-32.

Almeida, D. R. (2018). The constructivist turn in political representation and its challenges to democratic legitimacy: Lessons from participatory institutions in Brazil. Representation. https://doi.org/10.1080/ 00344893.2018 .1551241

Ankersmit, F. (2002). Political representation. Stanford, CA: Stanford University Press.

Arzheimer, K., \& Berning, C. C. (2019). How the alternative for Germany (AfD) and their voters veered to the radical right, 2013-2017. Electoral Studies, 60. https://doi.org/10.1016/j.electstud.2019.04.004

Barr, R. R. (2009). Populists, outsider, and antiestablishment politics. Party Politics, 15(1), 29-48.

Bunce, V. (1998). Regional differences in democratization: The East versus the South. Post-Soviet Affairs, 14(3), 187-211.

Buštíková, L., \& Guasti, P. (2019). The state as a firm: Understanding the autocratic roots of technocratic populism. East European Politics and Societies, 33(2), 302-330.

Castiglione, D. (2017). Outsider-insider's perspectives. Philosophy \& Social Criticism, 43(3), 292-293.

Collier, D. (1991). The comparative method: Two decades of change. In D. A. Rustow \& K. P. Erickson (Eds.), Comparative political dynamics (pp. 7-31). New York, NY: Harper Collins.

De Wilde, P. (2013). Representative claims analysis: Theory meets method. Journal of European Public Policy, 20(2), 278-294.

De Wilde, P. (2019). The quality of representative claims: Uncovering weakness in the defense of the liberal world. Political Studies, 1(22), 1-22.

Dias, T. (2017). É uma batalha de narrativas: Os enquadramentos de ação coletiva em torno do impeachment de Dilma Rousseff no Facebook [It is a battle of narratives: The collective action frames around Dilma Rousseff's impeachment on Facebook] (Master dissertation). University of Brasília, Brasília, Brazil.

Disch, L. (2011). Toward a mobilization conception of democratic representation. American Political Science Review, 105(1), 100-114.

Disch, L. (2015). The "constructivist turn" in democratic representation: A normative dead-end? Constellations, 22(4), 487-499.

Hartleb, F. (2015). Here to stay: Anti-establishment parties in Europe. European View, 14(1), 39-49.

Kaltwasser, C. R. (2014). The responses of populism to Dahl's democratic dilemmas. Political Studies, 62(3), 470-487.

Lieberman, E. S. (2005). Nested analysis as a mixedmethod strategy for comparative research. American Political Science Review, 99(3), 435-452.

Manin, B. (1997). The principles of representative government. Cambridge: Cambridge University Press.

Mansbridge, J. (2003). Rethinking representation. American Political Science Review, 97(4), 515-528.

Michailidou, A., \& Trenz, H. J. (2013) Mediatized representative politics in the European Union: Towards audience democracy? Journal of European Public Policy, 20(2), 260-277.

Moffitt, B. (2016). The global rise of populism: Performance, political style, and representation. Stanford, CA: Stanford University Press.

Mouffe, C. (2013). Agonistics: Thinking the world politically. London: Verso.

Movimento Brasil Livre. (n.d.). Parlamentares. Movimento Brasil Livre. Retrieved from http://mbl.org.br/ parlamentares

Mudde, C., \& Kaltwasser, C. R. (2011). Voices of the peoples: Populism in Europe and Latin America compared. South Bend, IN: Helen Kellogg Institute for International Studies.

Näsström, S. (2015). Democratic representation beyond election. Constellations, 22(1), 1-12.

Plotke, D. (1997). Representation is democracy. Constellations, 4(1), 19-34.

Rehfeld, A. (2006). Towards a general theory of political representation. The Journal of Politics, 68(1), 1-21.

Rodríguez Andrés, R. (2016). El ascenso de los candidatos outsiders como consecuencia de las nuevas formas de comunicación política y la desafección ciudadana [The rise of outsider candidates as a consequence of new forms of political communication and citizen disaffection]. Comunicación y Hombre, 12, 73-95.

Rosanvallon, P. (2008). Counter-democracy: Politics in an age of distrust (Vol. 7). Cambridge: Cambridge University Press.

Sartori, G. (1991). Comparing and miscomparing. Journal of Theoretical Politics, 3(3), 243-257. 
Saward, M. (2006). The representative claim. Contemporary Political Theory, 5(3), 297-318.

Saward, M. (2008). Representation and democracy: Revisions and possibilities. Sociology Compass, 2(3), 1000-1013.

Saward, M. (2010). The representative claim. Oxford: Oxford University Press.

Saward, M. (2014). Shape-shifting representation. American Political Science Review, 108(4), 723-736.

Saward, M. (2017). Agency, design, and 'slow democracy'. Time \& Society, 26(3), 362-383.

Schedler, A. (1996). Anti-political-establishment parties. Party Politics, 2(3), 291-312.

Schmitter, P. C. (2009). Re-presenting representation. Government and Opposition, 44(4), 476-490.

Taggart, P. (2018). Populism and 'unpolitics'. In G. Fitzi, J. Mackert, \& B. S. Turner (Eds.), Populism and the crisis of democracy. Volume 1: Concepts and theory (pp. 79-87). New York, NY: Routledge.

Tarrow, S. (2010). The strategy of paired comparison: Toward a theory of practice. Comparative Political Studies, 43(2), 230-259.
Tatagiba, L., Trindade, T., \& Teixeira, A. C. C. (2015). Protestos à direita no Brasil (2007-2015) [Right-wing protests in Brazil]. In S. V. e Cruz, A. Kaysel, \& G. Codas (Eds.), Direita, volver! O retorno da direita $e$ o ciclo político brasileiro [The right returns! The return of the right-wing and the Brazilian political cycle] (pp. 197-212). São Paulo: Editora Fundação Perseu Abramo.

Urbinati, N. (2006). Representative democracy: Principles and genealogy. Chicago, IL: University of Chicago Press.

Urbinati, N. (2010). Unpolitical democracy. Political Theory, 38(1), 65-92.

Urbinati, N. (2019). Judgment alone: Cloven citizenship in the era of the Internet. In D. Castiglione \& J. Pollak (Eds.), Creating political presence: The new politics of democratic representation. Chicago, IL, and London: The University of Chicago Press.

Vieira, M. (2017). Reclaiming representation: Contemporary advances in the theory of political representation. New York, NY: Routledge.

\section{About the Authors}
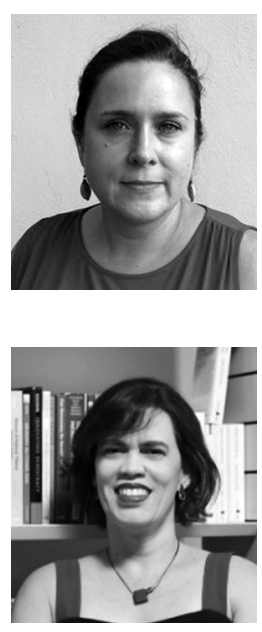

Petra Guasti is an Interim Professor at the Institute of Political Science, Goethe University Frankfurt (Democratic Innovations Unit). She was AY 2018/2019 Democracy Visiting Fellow at the Ash Centre for Democratic Governance and Innovation, Harvard Kennedy School. Her main research focus is democracy, more specifically the growing tension within the system of representative democracy in respect to its legitimacy. Her research appears among others in Democratization, Communist and PostCommunist Studies, European Political Science, East European Politics and Societies and Cultures and Politics and Governance.

Debora Rezende de Almeida is a Professor in the Institute of Political Science at the University of Brasília (Brazil). Her PhD dissertation, from Federal University of Minas Gerais, received the Honorable Mention from Capes in 2012 (Coordenação e Aperfeiçoamento de Pessoal de Nível Superior). She is the recipient of the 2016 Best Book Prize, awarded by the Brazilian Political Science Association, for her book Representação Além das Eleições. She has published articles on political representation theory and civil society participation in Critical Policy Studies and Representation, among others. 